\title{
COPROLOGICAL STUDY OF GASTROINTESTINAL PARASITES IN DAIRY CATTLE IN SULAYMANIYAH PROVINCE, KURDISTAN REGION, IRAQ
}

\author{
ARAM, A. M. \\ Department of Microbiology, College of Veterinary Medicine, Sulaimani University, Iraq \\ e-mail: aram.mohammed@univsul.edu.iq; phone:+964-770-157-1306 \\ (Received $4^{\text {th }}$ May 2020; accepted $16^{\text {th }}$ Sep 2020)
}

\begin{abstract}
Gastrointestinal (GI) parasitic diseases are a serious problem in cattle management, and one of the most significant reasons for economic losses incattle for developing countries. This study aimed to assessthe prevalence of helminth and protozoan infection of gastrointestinal tract in local dairy cattle in Sulaymaniyah province of Iraq.A total of 1,376rectal fecal specimens of local dairy cattle were randomly collected in different regions of Sulaymaniya province. Direct fecal smear, saturated sugar flotation technique, and simple sedimentation method, were used to detect the parasitic stages in the coprological specimens.The overall prevalence rate was $60.46 \%$.The single and mixed parasite infection rates were $37.21 \%$ and $23.25 \%$, respectively. The infection rates of protozoa, nematodes, trematodes, and cestodes were $58.14 \%, 18.60 \%, 15.11 \%$, and 3.48\%, respectively. Among all parasites, Eimeria spp. (29.07\%) was the most abundant one, followed by Buxtonella sulcata (18.60\%) and Strongyle nematodes (17.44\%). There was significant variation in the prevalence rates of nematodes and protozoa between various age categories and distributional regions. The results indicated that improved management system and proper anthelmintic treatment strategies should be applied in the regions to diminish the high incidence of GI parasitismin local dairy cattle.
\end{abstract}

Keywords:prevalence, helminthes, protozoa, livestock,fecal analysis

\section{Introduction}

Parasitosis is one of the biggest issues affecting livestock especially cattle of all age and breed categories (Rafiullah et al., 2011;Awraris et al., 2012). The endoparasites intervene with dietary status, growing process and byproductsof the cattle population (Pilarczyket al., 2009; Awraris et al., 2012; Khan et al., 2013).

The animals' gastrointestinal tract holds a broad range of parasitic protozoa and helminthes, which cause sub clinical and clinical parasitic infestation. These internal parasites inauspiciously affect the health conditions of animals and cause great economic impacts on the livestock industry (Wimmer et al., 2004; Bilal et al., 2009).

In the case of rearingfarm animals for food production, investigations that aid in evaluating the economic impacts caused by parasitic infestation are significant, particularly in smallholder farming structures in developing countries (Perry and Randolph, 1999; Sahoo et al., 2002). As parasites may cause clinical and nonclinical parasitism leading to economic losses, the purpose of veterinarians and producers is to avoid parasitism via goodhusbandry,adequate nutrition, control of epidemiological factors, and effective therapeutic treatment (McDermottet al., 1999; Kaewthamasornand Wongsamee, 2006).

Although the numbers of studies havereported the prevalence of gastrointestinal (GI) parasite of ruminants inIraq (Al-Taee et al., 2011; Nassrullah, 2011; Nasrullah et al., 2014; Minnat, 2014; Al-Zandee et al., 2016; Hassan et al., 2018; Al-Robaiee et al., 2019), there is no published study available related to GI parasites of cattle in the province of Iraq. Thus, the objective of the current studywas to record the prevalence of 
GI parasites among local dairy cattle in different regions of Sulaymaniyah province. The recorded data will provide fundamental knowledge of GI parasite infection levels in the province and it could be supportive for control strategies.

\section{Materials and Methods}

\section{Study area and sample population}

This study was conducted in Sulaymaniyah province, Kurdistan Region, north-east of Iraq. It is located between $35^{\circ} 04^{\prime}-36^{\circ} 30^{\prime}$ latitude and $44^{\circ} 50^{\prime}-46^{\circ} 16^{\prime}$ longitude. The area is characterized by seasonal rainfall from October to May, and inadequate farmer awareness about the husbandry and control of the endoparasites in the ruminants. Cattle population in the study regions (Penjwen, Chwarta, Said Sadq, and Piramagroon) is estimated to 40,355 according to the data recorded by Sulaymaniyah Veterinary Directorate in December 2015.

A total of 1,376 rectal fecal specimens of local dairy cattle, involving560 calvesand 816 cows, were randomly collected from different regions of Sulaymaniyah province. Among these samples, 200 were collected from Penjwen, 330 from Chwarta, 470 from Said Sadq, and 376 from Piramagroon. The samples were stored at $4{ }^{\circ} \mathrm{Cuntil}$ parasitological assessment. The age groups of cattle were sorted as calves (under1 year old) and cows (above 1 year old).The sampling period was begins from March to August 2018.

\section{Parasitological analysis}

Fecal specimens were analyzed for the existence of helminth eggs, protozoan oocysts and cysts,applying the simple flotation technique using saturated sugar solution (Sheather's sucrose solution). A simple sedimentation procedure was utilized to find the ova of flukes and some other nematodes and cestodes, whose ova do not recover in a saturated sugar solution. For diagnosis of protozoan trophozoites, the direct fecal smears were performed. The parasitic stages were identified based on morphological keys (Urquhart et al., 1994; Zajac and Conboy, 2012; Kandasamy et al., 2013).

\section{Statistical interpretation}

The data calculated by Chi-square $\left(\mathrm{X}^{2}\right)$ test using SPSS ${ }^{\circ}$ software V.25. The probability values below 0.05 were considered statistically significant.

\section{Results}

Out of 1,376 fecal samples examined, the overall infestation rate of GI parasite was60.46\%. The single and mixed parasite infection rates were $37.21 \%$ and $23.25 \%$, respectively with statistically significant differences. Eimeria spp. was the most dominant parasite that recognized in majority of multiple infections (Table 1).

This study found that the highest prevalence ofprotozoan infection was (58.14\%), followed by nematodes $(18.60 \%)$, trematodes $(15.11 \%)$, and cestodes $(3.48 \%)$. There was significant variation in the prevalence rates of nematodes and protozoa between various age categories and distributional regions (Table 2; Fig. 1; Fig. 2). 
Table 1.Prevalence of gastrointestinal parasites in local dairy cattle $\left(N^{a}=1,376\right)$ in Sulaymaniyah province

\begin{tabular}{|c|c|c|}
\hline Species of parasite & No. $^{b}(\%)$ & $P$-value \\
\hline \multicolumn{2}{|l|}{ Single parasitic infection } & \multirow{26}{*}{$<0.001$} \\
\hline Eimeria spp. & 144(10.46) & \\
\hline Buxtonella sulcata & $176(12.80)$ & \\
\hline Strongyle type & $96(6.97)$ & \\
\hline Cryptosporidium spp. & $48(3.49)$ & \\
\hline Dicrocoelium dendriticum & $48(3.49)$ & \\
\hline Subtotal & $512(37.21)$ & \\
\hline Multiple parasitic infection & & \\
\hline Eimeria spp. + Strongyle type & $64(4.65)$ & \\
\hline Eimeria spp. + Cryptosporidium spp. & $32(2.32)$ & \\
\hline Eimeria spp. + Buxtonella sulcata & $16(1.16)$ & \\
\hline Eimeria spp. +Moniezia spp. & $16(1.16)$ & \\
\hline Eimeria spp. + Toxocara vitulorum & $16(1.16)$ & \\
\hline Eimeria spp. + Fasciola spp. & $16(1.16)$ & \\
\hline Eimeria spp. + Paramphistomum cervi + Fasciola spp. & $16(1.16)$ & \\
\hline Eimeria spp. + Cryptosporidium spp. + Moniezia spp. & $16(1.16)$ & \\
\hline Eimeria spp. + Paramphistomum cervi + Buxtonella sulcata & $16(1.16)$ & \\
\hline $\begin{array}{c}\text { Eimeria spp. }+ \text { Paramphistomum cervi }+ \text { Buxotenella sulcata }+ \text { Strongyle } \\
\text { type }\end{array}$ & $16(1.16)$ & \\
\hline $\begin{array}{c}\text { Eimeria spp. }+ \text { Cryptosporidium spp. }+ \text { Paramphistomum cervi }+ \text { Fasciola } \\
\text { spp. }\end{array}$ & 16(1.16) & \\
\hline $\begin{array}{c}\text { Eimeria spp. + Cryptosporidium spp. +Moniezia spp. + Fasciola spp. + } \\
\text { Buxtonella sulcata }\end{array}$ & $16(1.16)$ & \\
\hline Strongyle type + Cryptosporidium spp. & $16(1.16)$ & \\
\hline Strongyle type + Paramphistomum cervi & $16(1.16)$ & \\
\hline Strongyle type + Fasciola spp. & 16(1.16) & \\
\hline Strongyle type + Buxtonella sulcata & $16(1.16)$ & \\
\hline Subtotal & $320(23.25)$ & \\
\hline Total (Overall) & $832(60.46)$ & \\
\hline
\end{tabular}

${ }^{\mathrm{a} N o .}=$ total number of examined cattle, ${ }^{\mathrm{b}}$ No. $=$ number of infected cattle

It was recorded three kinds of protozoan cysts/oocysts or trophozoites in the examined fecal samples, namely Eimeria spp. (29.07\%), Buxtonella sulcata (18.60\%), and Cryptosporidium spp. (10.46\%). The prevalence of Eimeria spp. in calves $(35.89 \%)$ was statistically higher than in cows $(24.38 \%)$, while Cryptosporidium spp. was significantly lower in calves $(6.96 \%)$ than cows $(12.86 \%)$. The increasing prevalence of $B$. sulcata associated with an expansion in age.

In the current investigation, the recognized nematode eggs included Strongyle nematodes and Toxocara vitulorum. Strongyle nematode (17.44\%) was the most predominant species detected in local dairy cattle, and the commonness in Piramagroon was fundamentally higher than those in other regions. T. vitulorum was recovered in 16 cattle. 
Table 2.Risk factors associated with prevalence of gastrointestinal parasites in local dairy $\operatorname{cattle}\left(N^{a}=1,376\right)$ in Sulaymaniyah province

\begin{tabular}{|c|c|c|c|c|c|c|c|c|c|}
\hline \multirow{3}{*}{$\begin{array}{l}\text { Species of } \\
\text { parasites }\end{array}$} & \multirow{3}{*}{\begin{tabular}{|c|} 
Prevalence \\
$\begin{array}{c}\text { No. } \\
(\%)\end{array}$ \\
\end{tabular}} & \multicolumn{3}{|c|}{ Age category } & \multicolumn{5}{|c|}{ Region } \\
\hline & & \multirow{2}{*}{\begin{tabular}{|c|} 
Calf \\
$\left(n^{c}=560\right)$
\end{tabular}} & \multirow{2}{*}{\begin{tabular}{|c|} 
Cow \\
$\left(n^{c}=816\right)$
\end{tabular}} & \multirow{2}{*}{$\begin{array}{c}P \text { - } \\
\text { value }\end{array}$} & \multirow{2}{*}{\begin{tabular}{|l|} 
Penjwen \\
$\left(n^{\mathrm{c}}=\mathbf{2 0 0}\right)$ \\
\end{tabular}} & \multirow{2}{*}{$\begin{array}{l}\text { Chwarta } \\
\left(n^{c}=330\right)\end{array}$} & \multirow{2}{*}{\begin{tabular}{|c|} 
Said Sadq \\
$\left(\mathrm{n}^{\mathrm{c}}=\mathbf{4 7 0}\right)$
\end{tabular}} & \multirow{2}{*}{\begin{tabular}{c|} 
Piramagroon \\
$\left(n^{c}=376\right)$
\end{tabular}} & \multirow{2}{*}{$\begin{array}{c}P \text { - } \\
\text { value }\end{array}$} \\
\hline & & & & & & & & & \\
\hline Protozoa & $800(58.14)$ & $303(54.10)$ & $497(60.90)$ & $<0.01$ & $110(55.00)$ & $170(51.51)$ & $295(62.76)$ & 225(59.84) & $<0.01$ \\
\hline Eimeria spp. & $400(29.07)$ & 201(35.89) & $199(24.38)$ & $<0.001$ & $56(28.00)$ & $76(23.03)$ & $145(30.85)$ & $123(32.71)$ & $<0.02$ \\
\hline $\begin{array}{l}\text { Buxtonella } \\
\text { sulcata }\end{array}$ & $256(18.60)$ & $63(11.25)$ & 193(23.65) & $<0.001$ & $39(19.50)$ & $72(21.81)$ & $117(24.89)$ & $28(7.44)$ & $<0.001$ \\
\hline $\begin{array}{c}\text { Cryptosporidiu } \\
m \text { spp. } \\
\end{array}$ & $144(10.46)$ & $39(6$ & $105(1$ & $<0.001$ & 15( & $22(6$ & 33( & 74 & $<0.001$ \\
\hline Nematodes & $256(18.60)$ & $143(25.53)$ & $113(1$ & $<0.001$ & $32(16.00)$ & $44(13.33)$ & 92(19.57) & 88( & $<0.001$ \\
\hline Strongyles & $240(17.44)$ & $137(24.46)$ & $103(12.62)$ & $<0.001$ & $31(15.50)$ & $40(12.12)$ & $82(17.44)$ & $87(23.13)$ & $<0.001$ \\
\hline $\begin{array}{l}\text { Toxocara } \\
\text { vitulorum }\end{array}$ & $16(1.16)$ & $6(1.07)$ & $10(1.22)$ & 0.79 & $1(0.50)$ & $4(1.21)$ & $10(2.12)$ & $1(0.26)$ & 0.06 \\
\hline Trematodes & $208(15.11)$ & 43(7.67) & $165(20.22)$ & $<0.001$ & $37(18.50)$ & 51(15.45) & 78(16.59) & 42(11.17) & 0.06 \\
\hline $\begin{array}{c}\text { Paramphistom } \\
\text { um cervi }\end{array}$ & $80(5$ & $10(1.7$ & $70(8.57)$ & $<0.001$ & $35(17.50)$ & $20(6.06)$ & $17(3.61)$ & $8(2$. & $<0.001$ \\
\hline Fasciola spp. & $80(5.81)$ & $24(4.28)$ & $56(6.86)$ & $<0.04$ & $1(0.50)$ & $30(9.09)$ & $25(5.31)$ & $24(6.38)$ & $<0.001$ \\
\hline $\begin{array}{c}\text { Dicrocoelium } \\
\text { dendriticum }\end{array}$ & $48(3.48)$ & $9(1.60)$ & $39(4.77)$ & $<0.001$ & $1(0.50)$ & $1(0.30)$ & $36(7.65)$ & $10(2.65)$ & $<0.001$ \\
\hline Cestodes & & & & & & & $17(3.61)$ & & $<0.001$ \\
\hline Moniezia spp. & $48(3.48)$ & $18(3.21)$ & $30(3.67)$ & 0.290 & $1(0.50)$ & $2(0.60)$ & $17(3.61)$ & $28(7.44)$ & $<0.001$ \\
\hline
\end{tabular}

${ }^{\mathrm{a}} \mathrm{N}=$ total number of examined cattle, ${ }^{\mathrm{b}}$ No. $=$ number of infected cattle, ${ }^{\mathrm{c}} \mathrm{n}=$ number of examined cattle
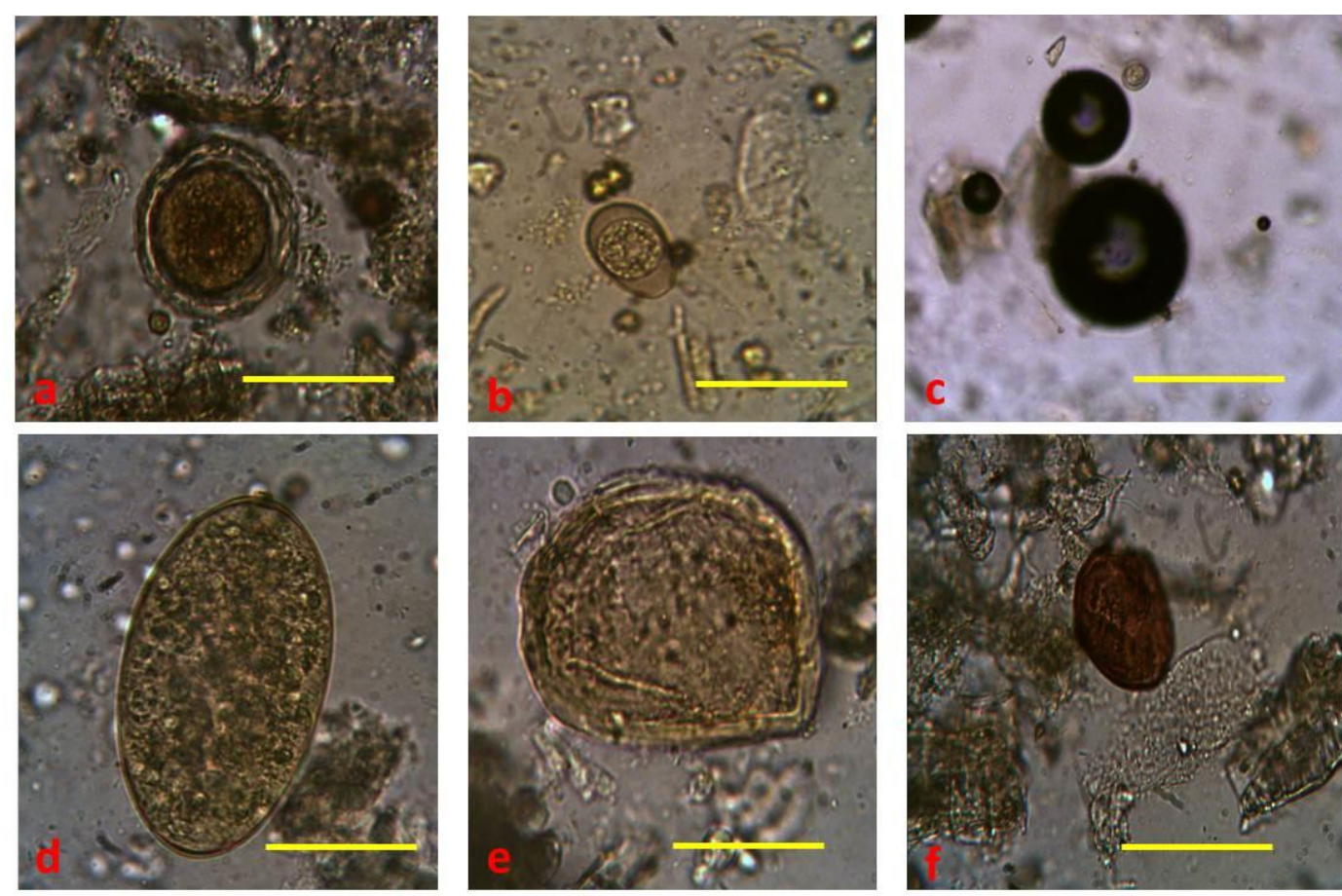

Figure 1.Fecal smears of cattle under the X40 objective microscope, scale bars are $100 \mu$ m:a. Toxocara vitulorum (egg); b. Eimeria spp. (oocyst); c. Cryptosporidium spp. (oocyst);d.

Fasciola spp. (egg); e. Moniezia spp. (egg); f. Dicrocoelium dendriticum (egg) 

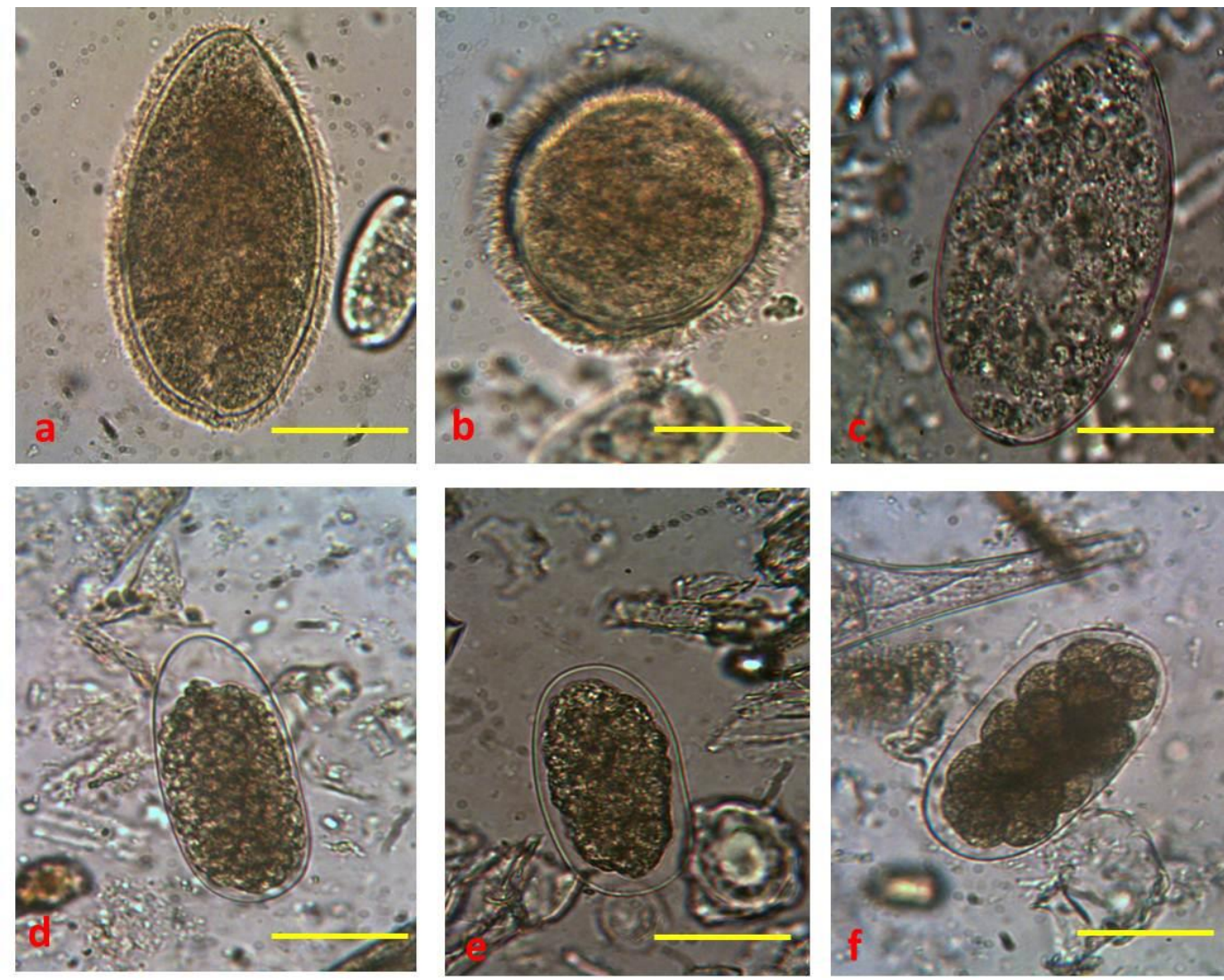

Figure 2.Fecal smears of cattle under the X40 objective microscope, scale bars are 100 um:a. Buxtonella sulcata (trophozoite); b.Buxtonella sulcata (cyst); c. Paramphistomum cervi (egg); d.; e.;f. Strongyle type(eggs)

The infection rate of trematodes $(15.11 \%)$ was comparatively lower than that of nematodes and protozoa. The identified trematodes involved Paramphistomum cervi (5.81\%), Fasciola spp. (5.81\%), and Dicrocoelium dendriticum (3.48\%). There was apparent variation between different age groups and different regions for these flukes infection.

The prevalence of tapeworms $(3.48 \%)$ was markedly lower than that of other parasites. Moniezia spp. eggs only recovered among infected cattle. There was no obvious difference between age categories of cattle; however, the prevalence rates in Piramagroon and Said Sadq regions were statistically higher than those in Chwarta and Penjwen areas.

\section{Discussion}

Control of GI parasitic diseases in livestock requires comprehensive information about the epidemiology, field management, and environmental conditions such as rainfall and temperature. The numbers of protozoan oocysts and helminth eggs developed inside the host animals vary according to the parasite species, degree of host susceptibility, the health,and immune status of the animals (Sharma and Busang, 2013).

Gastrointestinal nematode diseases of cattle continue to be a limitation on the proficient raising of cattle all through the world. In much less developed agricultural 
systems, parasitic infections may also cause serious clinical signs, such as stunted growth, tissue edema, and diarrhea (Gasbarre et al., 2001).Indeed in well-managed herds with no signs and symptoms of parasitism, the existences of GI parasites restrict the growth inyoung animals and diminish milk production in growing-up bovines (Hawkins, 1993).In Sulaymaniyah province of Iraq, infections triggered by GI parasites are predominant in small ruminants since of the helpful local weather for the transmission of infection (Nassrullah et al., 2014).

With this study, the findings demonstrated highly GI parasitic infections in cattle $(60.46 \%)$ in the Sulaymaniyah province of Iraq. The results are consistent with other reports from a number of countries (Regassa et al., 2006; Tung et al., 2012; Huang et al., 2014; Hussain et al., 2014; Hamid etal., 2017). These high levels of infection rate have reflected the lack of success from the de-worming program and highlighted ineffective husbandry.

In present research recorded a high prevalence of protozoan infection $(58.14 \%)$. This finding was similar to the consequence of the studies mentioned by Tung et al. (2012) and Huang et al. (2014).During the current study, a significantly higher proportion of calves (35.89\%) were infectedwith Eimeria spp. than cows (24.38\%). A recent investigation carried out in Sri Lanka has also recorded the similar findings (Gunathilaka et al., 2018). This might be due to the excessive humidity and reasonable temperature encourages the survival and sporulation of the oocysts. As their immunity is additionally lower than the adult cattle, calves might bemore susceptible to coccidian diseases (Bilal et al., 2009).B. sulcata infection was the second most dominant protozoan infection found in $18.60 \%$ of the local dairy cattle in the present study, and the increasing prevalence correlated with the rising in age. This finding was lower than the results of a previous research performed in Iraq (Al-Bakri et al., 2010).Fox and Jacobs (1986) showed that the quantity of carbohydrate in the food would affect the population growth or decrease of $B$. sulcata. The variation in the prevalence of infection may be due to differentfactors, such as environment, farm management practices and stress factors.Cryptosporidium spp. was the third protozoa recorded $10.46 \%$ of cattle with a significantly higher prevalence of infection in cows compared to calves. However,Roy et al. (2006) indicated calves to be most susceptible to infection and they also actas reservoirs.

According to the results of the current investigation, nematodes infected $18.60 \%$ of local dairycattle. The infection rate was markedly lower than a recentstudy conducted by Hamid et al. (2017).Improper antihelmintic administration, poor husbandry, or the evasion of immune responses might accelerate the risk of nematode infection.

In this study, P. cervi (5.81\%)and Fasciola spp. (5.81\%) were the most abundant trematodes followed by $D$. dendriticum (3.48\%). On the contrary, this result was higher than that registered by Tung et al. (2012). Environmental pollution may be one of the factors that reduce the number of snail population in the areas.Additionally, feeding fresh grass contaminated with metacercaria to their cattle from farmers could increase the risk of trematode infection.

During this research, Moniezia spp. was infected a very low proportion of cattle. A similar observation was reported by Jittapalapong et al. (2011). The variation in the prevalence rate of monieziasis between distributional regions may be due to the distribution of intermediate host, the free-living soil mites on pasture, in these regions. 


\section{Conclusion}

To the best knowledge, this is the first report on prevalence of GI parasites in Cattle in Sulaymaniyah province, Iraq. This study showed a high rate of GI parasites in cattle and it was concluded that GI parasite was common and endemic in the study areas. In addition to that, Eimeria spp. and Strongyle nematodes were the most abundant parasites recovered in the cattle. The farmers should apply improved management systems and regular de-worming treatments for controlling and prevention of parasitic diseases. Future investigations are essential to evaluate the economic impact of GI parasites in the study regions.

Acknowledgements. The author would like to thank the Sulaymaniyah Veterinary Directorate, Sulaymaniyah province, Kurdistan Region, Iraq for its facilities provided. The author also wishes to great thanks the owners of selected cattle farms in the study regions.

\section{REFERENCES}

[1] Al-Bakri, H. S., Suliman, E. G., Al-Saffar, T. M. (2010): Prevalence of intestinal ciliate Buxtonella sulcata in cattle in Mosul. - Iraqi Journalof Veterinary Sciences24(1): 27-30.

[2] Al-Robaiee, I., Sabah, Z., Ahmed, K., Salih, S. A. (2019): Diagnostic study of ovine gastrointestinal parasites in kirkuk city, Iraq. - Advances in Animal and Veterinary Sciences7(9): 727-731.

[3] Al-Taee, A. E. A., Taher, D. M., Yaqoob, V. S. (2011): Epidemiological study about prevalence and distribution of sheep and goats gastrointestinal parasites in Duhok province. - In: Animal hygiene and sustainable livestock production. Proceedings of the XVth International Congress of the International Society for Animal Hygiene, Vienna, Austria, 3-7 July 2011, Volume 1: 387-389. Tribun EU.

[4] Al-Zandee, M. T., Essa, H., Jabary, O. M., AL-Shateri, A. A., AL-Bajalan, Y. K. (2016):Identification of internal parasites in sheep and goats in Garmiyan province/Kurdistan Region/Iraq. - Journal of Zankoy Sulaimani (Pure andApplied Science) 18(4): 43-50.

[5] Awraris, T., Bogale, B., Chanie, M. (2012): Occurrence of gastro intestinal nematodes of cattle in and around Gondar town, Amhara regional state, Ethiopia. - Acta Parasitologica Globalis3(2): 28-33.

[6] Bilal, M. Q., Hameed, A.,Ahmad, T. (2009): Prevalence of gastrointestinal parasites in buffalo and cow calves in rural areas of Toba Tek Singh, Pakistan. - Journal of Animal and Plant Sciences 19(2): 67-70.

[7] Fox, M. T., Jacobs, D. E. (1986): Patterns of infection with Buxtonella sulcata in British cattle. - Research in Veternary Science41(1): 90-92.

[8] Gasbarre, L. C., Leighton, E. A., Sonstegard, T. (2001): Role of the bovine immune system and genome in resistance to gastrointestinal nematodes. - Veterinary Parasitology98(1-3): 51-64.

[9] Gunathilaka, N., Niroshana, D., Amarasinghe, D., Udayanga, L. (2018): Prevalence of gastrointestinal parasitic infections and assessment of deworming program among cattle and buffaloes in Gampaha District, Sri Lanka. - BioMed Research International2018:3048373.

[10] Hamid, P. H., Kristianingrum, Y. P., Prastowo, J., Da Silva, L. M. R. (2017): Gastrointestinal parasites of cattle in Central Java. - American Journalof Animal and Veterinary Sciences11(3): 119-124. 
[11] Hassan, H. F., Barzinji, A. K. R. (2018): Prevalence of ruminants gastro-intestinal parasites in Kirkuk province, Iraq. - Kirkuk University Journal forScientific Studies13(3):96-108.

[12] Hawkins, J. A. (1993): Economic benefits of parasite control in cattle. - Veterinary Parasitology46(1-4): 159-173.

[13] Huang, C. C., Wang, L. C., Pan, C. H., Yang, C. H., Lai, C. H. (2014): Investigation of gastrointestinal parasites of dairy cattle around Taiwan. - Journal of Microbiology, Immunology and Infection47(1): 70-74.

[14] Hussain, T., Periasamy, K., Nadeem, A., Babar, M. E., Pichler, R.,Diallo, A. (2014): Sympatric species distribution, genetic diversity and population structure of Haemonchus isolates from domestic ruminants in Pakistan. - Veterinary Parasitology206(3-4): 188199.

[15] Jittapalapong, S., Sangwaranond, A., Nimsuphan, B., Inpankaew, T., Phasuk, C., Pinyopanuwat, N., Chimnoi, W., Kengradomkij, C., Arunwipat, P., Anakewith, T. (2011): Prevalence of gastro-intestinal parasites of dairy cows in Thailand. - Kasetsart Journal (NaturalScience)45:40-45.

[16] Kaewthamasorn, M., Wongsamee, S. A.(2006):Preliminary survey of gastrointestinal and haemoparasites of beef cattle in the tropical livestock farming system in Nan province, northern Thailand. - ParasitologyResearch 99:306.

[17] Kandasamy, G., Rajapakse, R.P.V.J., Rajakaruna, R.S. (2013): Gastrointestinal and blood parasites of a free grazing flock of sheep in Kaithady farm in the Jaffna District. - Journal of the National Science Foundation of Sri Lanka 41(3):195-201.

[18] Khan, J. M., Hussain, A., Bukhsh, A., Shumaila, M. (2013): Identification of Ostertagia ostertagi in cattle with persistent diarrhea. - Research Journal for Veterinary Practitioners1(2): 16-17.

[19] McDermott, J.J., Randolph, T.F., Staal, S.J.(1999):The economics of optimalhealth and productivity in smallholder livestock systems in developing countries. - Revue Scientifique et Technique 18:399.

[20] Minnat, T. R. (2014): Detection of gastrointestinal parasite infection of sheep and goats in Diyala Province-Iraq. - Al-Qadisiyah Journal of Veterinary Medicine Science13(2): 118123.

[21] Nassrullah, A. J. (2011): Prevalence of Gastrointestinal parasites in sheep in Sulamani province. - Al-Anbar Journal of Veterinary Sciences4(2): 34-36.

[22] Nasrullah, O. J., Slemane, R. R., Abdullah, S. H. (2014): Prevalence of the gastrointestinal tract parasite in goats in Sulaimani province. - AssiutVeterinary Medical Journal60: 25-28.

[23] Perry, B. D., Randolph, T. F. (1999): Improving the assessment of the economic impact ofparasitic diseases and of their control in production animals. - Veterinary Parasitology84(3-4): 145-168.

[24] Pilarczyk, B., Balicka-Ramisz, A., Kozak, W.,Ramisz, A. (2009): Occurrence of endoparasites in heifers imported to Poland from the Netherland. - Archiv fur Tierzucht52(3): 265-271.

[25] Rafiullah, T. A., Sajid, A., Shah, S. R., Ahmad, S., Shahid, M. (2011): Prevalence of gastrointestinal tract parasites in cattle of Khyber Pakhtunkhwa. - Journal of Agricultural andBiological Science 9: 6.

[26] Regassa, F., Sori, T., Dhuguma, R., Kiros, Y. (2006): Epidemiology of gastrointestinal parasites of ruminants in Western Oromia, Ethiopia. - International Journalof Applied Research in Veterinary Medicine4(1): 51.

[27] Roy, S. S., Sarkar, S., Batabyal, S., Pramanik, A. K., Das, P. (2006): Observations on the epidemiology of bovine cryptosporidiosis in India. - Veterinary Parasitology141(3-4): 330-333. 
[28] Sahoo, N., Mohanty, T. N., Samal, S. (2002): Prevalence of gastrointestinal helminthicinfection among grazing and stall-fed cattle in a rainfed district of Orissa. Journal of VeterinaryParasitology16(1): 61-62.

[29] Sharma, S. P. A. L., Busang, M. (2013): Prevalence of some gastrointestinal parasites of ruminants in southern Botswana. - Botswana Journalof Agriculture and Applied Sciences 9(2): 97-103.

[30] Tung, K. C., Huang, C. C., Pan, C. H., Yang, C. H., Lai, C. H. (2012):Prevalence of gastrointestinal parasites in yellow cattle between Taiwan and its Offshore Islands. - Thai Journal of Veterinary Medicine42(2): 219-224.

[31] Urquhart, G. M., Armour, J., Duncan, J. L., Dunn, A. M., Jennings, F. W. (1994): Veterinary Parasitology. $-1^{\text {st }}$ ed. Singapore, Longman.

[32] Wimmer, B., Craig, B. H., Pilkington, J. G., Pemberton, J. M. (2004): Non-invasive assessment of parasitic nematode species diversity in wild Soay sheep using molecular markers. - International Journal forParasitology34(5):625-31.

[33] Zajac, A. M., Conboy, G. A. (2012):Veterinary Clinical Parasitology. $-8^{\text {th }}$ ed. John Wiley $\&$ Sons. 